\title{
A Postscript for Charles Black: The Supreme Court and Race in the Progressive Era
}

\author{
Benno C. Schmidt, Jr.†
}

Charles Black's work in constitutional law is, ${ }^{1}$ like the "slow politics of the text"2 of the great Document itself, a statement of fundamental truths about our condition and aspirations that often takes a while to set in. As Harry Wellington has noted, few people had the sense to see The People and the Court ${ }^{3}$ when published in 1960 for what it should with deliberate speed have become: the dominant influence on my generation of constitutional lawyers' efforts to see the problem of judicial review beyond the shadows of the New Deal and the debacle of FDR's Court-Packing Plan. The book has, along with related works such as Decision According to $L a w,{ }^{4}$ constituted our era's main answer to the perennial anxiety that judicial review is a usurpation of democratic powers vested in the legislative and executive branches. Black has also been our era's main exponent of the related truth so hard for many to swallow: that courts have in fact and are invited by the "democratic branches" to have large powers for social change, powers that grow rather than dissipate with sensible, principled and high-minded use. At the same time, Black's approach is rooted in the insistence that judicial review is an exercise of law and not of fiat; no one is more withering about those who would turn to courts for a fix anytime the political processes prove deaf, slow or inconvenient. Indeed, Black's view that constitutional law must be rooted in principle has been the basis for one of his most important insights about judicial review, that its prime importance lies not in its checking function but rather in its capacity to give legitimacy to the exercise of governmental power.

Amid the reams of writing about the problem of constitutional interpretation, Charles Black's Edward Douglass White Lectures, Structure and

$†$ President, Yale University.

1. I do not use the past tense. See, e.g., his Samuel Rubin Lecture at Columbia given a few weeks ago, Black, Further Reflections on the Constitutional Justice of Livelihood, 86 Colum. L. REv. (forthcoming Oct. 1986), a vigorous and unorthodox statement of the relation of the Constitution to an asserted right of minimum material human dignity.

2. The phrase is borrowed from my Columbia colleague Edward Said.

3. C. Bi.acik, The Prople: and the Court (1960).

4. C. Bi.ack, Drcision According; TO LAw (1981). 
Relationship in Constitutional Law, ${ }^{\mathbf{b}}$ is recognized everywhere as a classic. This brilliant essay recalled our era to a time-honored and sensible mode of interpretation that goes a long way to preserving the domain of principle in constitutional law despite the inevitable shortcomings of textual exegesis.

For all of the importance of his general writings on constitutional law, for me Charles Black's greatest contributions have centered on the problem of racial justice, the problem, as I learned first from him, that is and always has been the central problem of American constitutional law. No one has added more to our understanding of law and race than Charles Black. With his Texan's sense of the reality of race relations, a grounding rooted both in his capacity for despair and in his faith in the ultimate claims of decency and justice, with his Southerner's gift for stirring our senses of beauty and tragedy with writing that has the feel of people and the smell of the earth, and with his long view of historical consciousness, Charles Black has changed the way all of us think about the Constitution and racial justice.

It was Black's article The Lawfulness of the Segregation Decisions ${ }^{8}$ that saw the invidious and purposeful segregation in Brown not as an isolated insult, but as one feature of a general system of racial subjugation historically rooted in slavery and the Black Codes. Moreover, Black saw that it must be the central, if sadly deferred, mission of the post-Civil War Amendments to outlaw this entire system. In thus generalizing the basis of Brown, Black's article offered a compelling defense of the decision against critics who attacked it as inconsistent with the Fourteenth Amendment's original intent, ${ }^{7}$ as a denial of freedom of association, ${ }^{8}$ and as an expression of political power not appropriate to the judiciary. ${ }^{\circ}$ Twenty years later, of course, the Supreme Court recognized that the core of equal protection jurisprudence rested on what Black had said in 1955, invidious purpose. ${ }^{10}$

A decade later, it fell again to Black to provide the critical principled defense of another race relations decision, Reitman v. Mulkey, ${ }^{11}$ which I

5. C. Black, Structure and Relationship in Constitutional Law (1969).

6. Black, The Lawfulness of the Segregation Decisions, 69 YALE L. J. 421 (1960).

7. See, e.g., R. Berger, Government By Judiciary 117-33 (1977).

8. Wechsler, Toward Neutral Principles of Constitutional Law, 73 Harv. L. Rev. 1, 34 (1959). In Wechsler's view, segregation was not an issue of "discrimination" but of "freedom of association." For him, the "challenge" of school segregation cases was to find neutral principals to decide between the competing association claims of segregationists and integrationists.

9. See, e.g., The "Southern Manifesto," signed by numerous Southern Senators and Representatives in 1954, 100 CoNG. REC. 725-57 (1954).

10. Washington v. Davis, 426 U.S. 229 (1976).

11. 387 U.S. 369 (1967) (holding California's anti-fair housing initiative to violate 14th Amendment). 
know Chief Justice Warren thought was the most important decision since Brown. Black's brilliant 1967 Forward in the Harvard Law Review $w^{12}$ gave this pivotal decision a foundation in reason that has stood the test of two decades, and it offered a perspective on the overall problem of state action that is the most persuasive in modern constitutional law scholarship.

Black lately has turned his attention to the constitutional implications of poverty, educational deprivation, and social degradation that menace our hopes for racial justice. ${ }^{13}$ It will be interesting to see over the next twenty years whether Black's approach to these problem has the same generative power as his earlier writing. Sadly, I have to say that I have my doubts.

In closing his renowned Edward Douglass White Lectures, Charles Black remarked on the striking truth that, during the Chief Justiceship of White, who was himself a Confederate veteran from Louisiana, the Supreme Court for the first time since Reconstruction held the line against the rampant racism that increasingly gripped the country from the 1890's on. ${ }^{14}$ I have thought Black's remarks captured a feeling of empathy across the years between Black, the Texan who became the preeminent constitutional theorist of racial justice, and Edward Douglass White, the child of Thibodaux, Lafourche Parish, who as Chief Justice, for all his limitations, joined in the Peonage Cases ${ }^{15}$ and Buchanan $v$. Warley, ${ }^{16}$ and took the lead in consigning the Grandfather Clause to that part of the constitutional scrapheap reserved for the most odious frauds on our legal order. ${ }^{17}$ Modest though this postscript is, I hope that it will deepen the historical and constitutional kinship between Black and White.

My own published work on the Supreme Court and race relations during the Progressive era has focussed on cases falling into the large constitutional categories of peonage, voting rights, Jim Crow laws, ${ }^{18}$ and jury discrimination. ${ }^{19}$ This organization left no obvious place for discussion of

12. Black, Forward: "State Action," Equal Protection, and California's Proposition 14, 81 HARV. L. Rkv. 69 (1967).

13. See, e.g., Black, supra note 1.

14. C. BI.ACK, supra note 5, at 97-98.

15. Bailey v. Alabama, 219 U.S. 219 (1911) (peonage law, making failure to perform labor contract a criminal offense, violates Thirteenth Amendment); United States v. Reynolds, 235 U.S. 133 (1914).

16. 245 U.S. 60 (1917) (city ordinance prohibiting colored persons from occupying certain property violates Fourteenth $\Lambda$ mendment right to equal enjoyment of property).

17. Guinn v. United States, 238 U.S. 347 (1915); Myers v. Anderson 238 U.S. 368 (1915) (state may not impose a standard for suffrage which existed prior to Fifteenth Amendment and was rendered unconstitutional thereby).

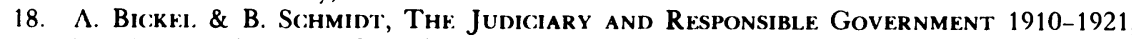
Part 2 (1984); Schmidt, Principle and Prejudice: The Supreme Court and Race in the Progressive Era (pts. 1-3), 82 Col.um. L. Rkv. 444 (1982), 82 Colum. L. Rev. 646 (1982), 82 Colum. L. Rev. 835 (1982).

19. Schmidt, Juries, Jurisdiction, and Race Discrimination: The Lost Promise of Strauder v. 
several decisions that fell outside the constitutional rubrics, but seemed revealing of the nature of race relations of the times and of the Supreme Court's reaction to it. This postscript treats those cases.

If it was a mistake not to include these cases before, as I now think, the mistake is not one Charles Black would have made. One of Charles Black's strengths as a constitutional law scholar is his sustained curiosity and expert knowledge about areas of law not embraced within constitutional law's sprawling manifest destiny. Among the important scholars of judicial review and constitutional interpretation, only Charles Black and one or two others can claim preeminence in a second major field of law. Black's other strength, of course, is Admiralty, in which the treatise he wrote with his late friend Grant Gilmore dominates the field. Black's penetrating engagement with this ancient body of law, not shaped in the main by the peculiar institution of Supreme Court constitutional review and not pulled and hauled by the tidal forces of constitutional history, has, I believe, strongly influenced his work in constitutional law. Charles Black's appreciation for qualities that are general in the law has imbued his constitutional law writing with liberating discipline, with realism about what one can and should expect from judges in the way of principled creativity, and with a professional's sense of proportion about the surmountable complexity and manageable doubt of legal interpretation. In tribute to Charles Black, this postscript travels the non-constitutional countryside to better appreciate and explain the more familiar landmarks of Progressive era constitutional adjudication.

Although racial separation, peonage, and voting rights were the areas of primary activity in the Supreme Court's work in the constitutional law of race relations during the Progressive era, race cases not involving, or at least not perceived to involve, great constitutional questions came to the White Court as well, and in two of these relatively obscure, uncharged cases the Justices' attitudes toward race relations stood sharply etched. The Court also revealed itself in roads not taken, in cases of would-be importance that were summarily disposed of without grappling with substantial questions of racial justice, or that elicited opinions while avoiding the confrontation of serious questions. The most notable area of abstention concerned the rampant racism of Southern criminal law administration, especially concerning the exclusion of blacks from Southern juries, the one important constitutional area of race relations where the White Court's record of achievement falls short of its predecessor, the Fuller Court.

West Virginia, 61 Tex. L. REv. 1401 (1983). 


\section{Jones V. Jones: The Final Word of "A Confederate THROUGH AND ThROUGH"}

Jones $v$. Jones ${ }^{20}$ was a modest case in which no obvious injustice was done, but which upheld a distinction in Tennessee's law that projected a legal disability based on slave birth into the Twentieth century. Disposed of complacently at the end of the 1913 Term by a unanimous Court, the case concerned the inheritance of 87 acres of land owned by John Jones, a black freedman who had died in 1889 leaving no children and no will. His widow claimed the estate under a Tennessee statute providing that a spouse should inherit when an intestate dies "leaving no heirs at law capable of inheriting the real estate."21 Tennessee's statute of descent preferred the brothers and sisters of an intestate to the spouse, but the Tennessee courts had construed this statute to cover only brothers and sisters born free of free parents. Children of slaves born as slaves, under the state court's construction, could not inherit as "heirs at law."22 Jones' siblings had given a quitclaim deed on the property to one Will Jones (unrelated so far as the record revealed), but since they had been born slaves, they were not "heirs at law" within the meaning of the Tennessee statutes of descent. The state courts awarded John Jones' land to his widow, and Will Jones took a writ of error to the Supreme Court.

Justice Lurton, affirming the judgment of a state court on which he had once served, explained that the Tennessee Supreme Court's construction was but an application of the common law principle that certain categories of persons, such as aliens and bastards, were excluded from general laws of descent because they lacked, in the vivid common law metaphor, "inheritable blood." In Tennessee and in other slave states, the "uninheritable blood" doctrine was merely an aspect of white society's general denial of black slaves' property rights, a detailed network of laws that Lurton summed up with a quotation from Kent's Commentaries: "They cannot take property by descent or purchase, and all they find, and all they hold, belongs to the master." 23 After emancipation, Lurton went on, former slave states passed statutes to give descendants of slaves rights of inheritance, but these statutes typically extended rights only to the chil-

20. 234 U.S. 615 (1914).

21. Shannon's Codr. Trin. $§ 4165$ (Thompson 1918).

22. Id.

23. Krnr's Commentarirs 278 (11th edition 1867), quoted in Jones v. Jones, 234 U.S. at 617. The eleventh edition, published two years after Appomattox and four years after emancipation, took no apparent notice of the anachronistic nature of its discussion of the law of slavery. The next edition, the first edited by Holmes, came out in 1873 and added this note, overly optimistic as it turned out, to the discussion of the law relating to slavery: "The abolition of slavery by the Thirteenth Amendment has put an end to the discussion formerly so numerous." 2 KENT's Commentaries 357 (12th ed. 1873). Evidently not. 
dren of slaves and not to their collateral relations. In Tennessee, for example, the collateral relations of former slaves were held even after the Civil War to possess no "inheritable blood." None of this, according to Lurton, concerned federal law. "Inheritance is governed by the lex rei sitae. It is not a natural or absolute right, but the creation of statute law." 24 If one's right to inheritance is denied "because he must trace his pedigree or title to or through an alien, a bastard or a slave, the question is one to be determined by the local law."25 It did not matter to Lurton that John Jones had acquired his 87 acres when he was a freedman. Will Jones' claim that this was discrimination against those born as slaves and violated the equal protection clause of the Fourteenth Amendment because his rights in the land were denied solely on account of the past slave status of his quitclaim grantors provoked a simple, shallow answer: "We are unable to see in the Tennessee statute of Descent any such denial of the equal protection of the law as is prohibited by the Fourteenth Amendment." 28

In defense of the Court's casual rejection of the constitutional claim, it must be said that no obvious injustice was done by the widow's victory over Will Jones. Perhaps this accounts for the surprising absence of any dissent, especially from Hughes and Day, but nothing in Lurton's discussion suggests that he was merely aiming at a just result. Both his untroubled elision of the equal protection issue and the antebellum tone of his discussions of the absence of rights of slaves and of Tennessee's partial-and generous, as he seemed to think-recognition of inheritance rights for freedmen, suggests that he was comfortable with the principle that former slave status could be the basis for the denial of rights of intestacy.

Although Lurton gave no justification for the exclusion of slaves and their offspring from collateral lines of descent, he did cite a North Carolina case, Tucker $v$. Bellamy, which justified the exclusion because:

after they were emancipated-became freedmen - it was practically impossible to trace their relationships by blood while they were slaves, with any tolerable degree of certainty. The confused condition of their family ties and relationships ... rendered it necessary to prescribe by statute who should be the heir at law, and from whom he might inherit. ${ }^{27}$

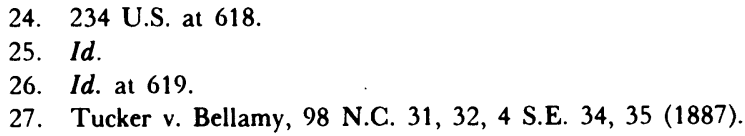


Identifying the spouse and children of a deceased freedman was presumably a simpler matter than identifying the siblings. ${ }^{28}$

Had a similar reason underlain the Court's decision, Jones $v$. Jones could be viewed narrowly as a restriction on intestate succession by brothers and sisters of former slaves, and not as sanctioning any broader principle that former slave status could be the basis for denying a wider range of inheritance rights. Even on the narrow view, however, the decision seems dubious under the Thirteenth Amendment, if not necessarily so under the relaxed equal protection doctrines of the day. For a state to deny any right, even a "non-vested" right such as intestate succession, on the basis of former slave status would appear to be a "badge of slavery" of precisely the sort that the Civil Rights Cases had said the Thirteenth Amendment prohibited of its own force. ${ }^{29}$ That the right in question was not "a natural or absolute right, but the creation of statute law," Lurton emphasized, should not have mattered. The Civil Rights Act of 1866 had ostensibly given all persons the same rights of inheritance as were enjoyed by whites. On the other hand, it must be allowed that the difficulty of proving collateral relations among persons born as slaves might have been thought to justify the Tennessee approach. The unanimity of the court suggests that this might have been the view of some of the Justices. Nevertheless, the Yale Law Journal, in the only notice taken of the decision in the law reviews, offered an approach more in keeping with the Thirteenth Amendment. It analyzed the question of collateral relation as one of fact: "if a negro can prove to the satisfaction of the court his line of descent . . . though it pass through slave ancestry, he should be entitled to the same consideration as a native born white person.",31

28. Lurton himself, while a judge on the Tennessee Supreme Court, had written an opinion in Brown v. Cheatham, 91 Tenn. 97 (1892), holding that slave marriages should be deemed legitimate in the eyes of the law.

29. The appellant's brief, a revelation of attitudes thought persuasive in this time, had argued:

$[\mathrm{T}]$ here is but one question actually involved in this lawsuit, and that is whether or not exslaves . . . are entitled to inherit from their brothers and sisters, who were likewise ex-slaves, and whether or not the mark of bondage will still remain upon the poor, unfortunate colored race, who served so faithfully their master before the Emancipation Proclamation by Mr. Lincoln, and who in fact to this day are as faithful to the white man as they were in the days of slavery.

It went on, embracing the distinction laid down in Plessy v. Ferguson, 163 U.S. 537 (1896):

This is not a case where social equality is undertaken to be enforced, but is a case where civil rights of persons of color or ex-slaves are attempted to be enforced. Were it a question of social equality it would be an entirely different proposition. . . .

Brief for $\Lambda$ ppellant at 7, 8, Jones v. Jones, 234 U.S. 615 (1914).

The brief for appellee, on the other hand, made two points, both of which appear in Justice Lurton's opinion. "The only right claimed is the right to inherit and that is not a natural right." And, "nothing is better settled than the proposition that questions of descent are to be determined by local law." Brief for $\Lambda$ ppellee at 8,13 .

30. 234 U.S. at 618.

$3 \rightarrow$ Comment, The Right of Inheritance of Freedmen Born of Slave Parents, 24 YALE L.J. 75, 
Horace Harmon Lurton handed down Jones v. Jones on June 22, 1914 , his last day of active service on the Supreme Court. He had recently returned from a four-month absence caused by illness, and death was but three weeks away. The opinion seems perhaps a fitting last word, both a remembrance of things past for the former fiery secessionist, and a statement of antebellum claims on the present and the future, as he blandly accepted a legal discrimination resting on former slave status in the law of his native state.

Lurton's record on the Supreme Court in cases involving the rights of blacks reveals a man untroubled by the state of race relations in the years before World War I. ${ }^{32}$ In Bailey v. Alabama ${ }^{33}$ the first Peonage Case, Lurton joined Holmes's dissent, fulfilling the pessimistic prophesies of those Progressive opponents of his appointment like Edward A. Moseley, Secretary of the Interstate Commerce Commission, who had written Taft that Lurton never spoke a word "in recognition of the right of those who toil." 34 There is convincing evidence that Lurton was set to dissent in the Grandfather Clause Cases, ${ }^{36}$ which did not come down until after his death, although whether he would merely have joined Lamar's dissent in United States v. Mosley ${ }^{38}$ on statutory construction, or whether he would have gone further into wholesale dissent on the constitutionality of the Grandfather Clause is not clear. ${ }^{37}$ Lurton was with the four who remained aloof from Hughes' insistence on equality in McCabe v. Atchison, Topeka $\mathcal{E}^{\mathrm{S}}$ Santa $\mathrm{Fe} R \mathrm{Ry} .{ }^{38}$ the Oklahoma luxury railroad car case, and, as we shall see, he joined Holmes's dissent in the Creswill case, ${ }^{39}$ which upheld the right of a black fraternal organization called the Knights of Pythias to use the same name as a white organization. To Theodore Roosevelt, Lurton might have been "right on the Negro question," 40 but in race rela-

77 (1914).

32. Lurton could support black aspirations when channeled along approved lines. On March 14, 1910, Lurton had written a letter to President Taft, exemplifying their close relationship even on matters far from judicial business, recommending the appointment of J.C. Napier of Nashville as Registrar of the United States Treasury, an appointment, as Lurton understood, that "is always set apart for some member of the colored race. . . Aside from Booker Washington, I believe he is the best representative of the colored race south of the Ohio River. He is in thorough accord with Booker Washington and accompanies him on many of his speaking and educational tours." Letter from Horace Lurton to President William H. Taft (Mar. 14, 1910), Taft Papers, Presidential Series No. 1A. Library of Congress, quoted $\rightarrow$ A. Bickel \& B. SCHMIDT, supra note 18, at 341 .

33. 219 U.S. 219 (1911) (peonage law, making failure to perform labor contract a criminal offense, violates Thirteenth Amendment).

34. Letter from Edward Moseley to President William H. Taft (Nov. 22, 1909), quoted in A. Bickei. \& B. SchmidT, supra note 18 , at 75 .

35. Guinn v. United States, 238 U.S. 347 (1915); Myers v. Anderson, 238 U.S. 368 (1915).

36. 238 U.S. 383,388 (1915) (Lamar, J., dissenting).

37. See A. Bickel. \& B. SCHмidT, supra note 18 , at 945-49.

38. 235 U.S. 151 (1914); see A. Bickel \& B. SCHmidT, supra note 18 , at $775-84$.

39. Creswill v. Knights of Pythias, 225 U.S. 246 (1912).

40. A. Bickil. \& B. SchmidT, supra note 18 , at 75 . There is reason to think that Theodore 
tions cases decided by the Supreme Court during his brief four-year tenure, Lurton was utterly content with looking backward. For, as Willis Van Devanter recalled in a vivid address years later, Lurton was "a Confederate through and through,"41 and as Hughes summed him up, a "typical judge of the old school."42

\section{Creswill v. Knights of Pythias: Separate, But Equal in NAME}

Creswill v. Knights of Pythias ${ }^{43}$ was a long, complicated decision handed down in 1912 that resorted to general principles of equity seemingly lacking any federal dimension in order to correct what Chief Justice White and a majority evidently saw as a palpable racial injustice. The case has puzzled several generations of students of federal jurisdiction. ${ }^{44}$

For some years, two fraternal and benevolent orders known as the Knights of Pythias had existed side by side, one for white males, one for black males, separate, to be sure, but equal as to name. This nominal parity became an affront to the white Knights in Georgia. The white Knights had been chartered in the District of Columbia by Congress, first in 1864 and subsequently by later federal incorporation statutes, and grand and subordinate lodges had been established in a number of states, including Georgia in 1871. The black Knights of Pythias was originally established in Mississippi in 1880, and under the name "The Supreme Lodge Knights of Pythias, North and South America, Europe, Asia, and Africa" became a District of Columbia corporation by virtue of Congressional charter in 1889. The black Knights also established a Grand Lodge in Georgia, informally in 1886, and by formal designation of the Supreme

Roosevelt did not know a great deal about Lurton when he wrote this or, at least, that what he did know came by way of Lurton's perennial sponsor, close friend, and former colleague on the Sixth Circuit Court of Appeals, William Howard Taft. In an effort to calm Lodge's agitation against Lurton, Roosevelt had written that Lurton was "right on the Negro question; he is right on the power of the Federal Government; he is right about corporations; and he is right about labor." Id. But when E.A. Moseley, Secretary of the Interstate Commerce Commission, at the request of Attorney General Moody, investigated Lurton's positions in cases involving the federal commerce power, he reported: "With one exception, Judge Lurton has decided against the contention of the Government in every case under the Interstate Commerce law which has come before him." This, of course, killed Lurton's chances with Roosevelt. Heffron, Profile of a Public Man, in Yearbook 1980, Sup. Cr. Hist. Soc. 30,34 . There is no reason to suppose that Roosevelt knew any more about Lurton's attitudes toward race relations than he did about his positions on the commerce power.

41. W. Van Devanter, Address to The Colorado Bar Association, Fortieth Annual Meeting 60-68 (H. Humphreys ed., Sept. 10-11, 1937).

42. C. Hughes, Biographical Notes, Microfilm, Ac. 9943, p. 220, Library of Congress.

43. 225 U.S. 246 (1912).

44. See P. Bator, P. Mishkin, D. Shapiro \& H. Wechsler, The Federal Courts and the FEDERAL SYSTEM 524 (2d ed. 1972); Hill, The Inadequate State Ground, 65 Colum. L. Rev. 943, 970 n.106 (1965). 
Lodge in 1890. According to the Georgia courts, there were some 300,000 black Knights nationwide, with about 30,000 members in Georgia.

In 1905, when the black Knights' Grand Lodge in Georgia applied to the state courts to be chartered as a domestic Georgia corporation, the white Knights petitioned the state court not only to prevent the incorporation but also to enjoin the black Knights from using the name insignia, emblems, etc. of the Knights of Pythias. The white Knights argued that such use infringed their interest in the name and was a fraud on the public. The black Knights presented a number of defenses to this petition. The black Knights contended that they had a right to the name under the Congressional charter, and that since the public well knew that there were two, racially distinct Knights of Pythias, there was no danger of fraud. Moreover, the black Knights insisted that because the two orders had existed side by side in harmony for many years the white Knights were barred from relief by the equitable doctrine of laches, a doctrine requiring timely objection to alleged equitable infringements rooted in policies of estoppel and the notion that there can be little injury if the victim has let matters slide. The white Knights eventually prevailed in the Georgia courts, and a decree issued in 1908 denying the black Knights the right to incorporate in Georgia and barring them from using the name Knights of Pythias. ${ }^{45}$

When the case came before the Supreme Court on writ of error, Chief Justice White, for the majority, was obviously determined to reverse this decision, but he faced considerable difficulties in figuring out how to do so. ${ }^{46}$ White was clear that the right of the black Knights to use the name was a right or privilege claimed under federal law, and that in denying this right the Georgia courts had relied not on any state statute but on "principles of general law" applicable to trademarks and tradenames. Therefore, the state courts' application of these general principles was subject to Supreme Court review. White accepted, for purposes of the appeal, though carefully indicating doubts, that the Georgia courts were right in deciding that benevolent orders had a legal interest in exclusive use of their name, and that the white Knights, having had the name first in time thereby had a right to prevent injury caused by another's use of the same name. But the question of laches was also a matter of general law, White insisted. Now it was true, White said, that state court findings of fact were not as such subject to review by the Supreme Court on writ of error, but where a federal right and findings of fact were so intermingled that protecting the right required analyzing the facts, the Supreme Court

45. Creswill v. Knights of Pythias, 133 Ga. 837, 67 S.E. 188 (1910).

46. In the Supreme Court, the black Knights were represented by Alton B. Parker, among others. Creswill, 225 U.S. at 247. 
must review the facts as well as the law. White then made a swift thrust and retreat. He insisted that the evidence did not support at all the conclusions of the state court that the black Knights intended to defraud the public, or that their use of the name in any way injured the white Knights. "But strong as are our convictions as to these subjects, we prefer not to rest our conclusion upon them, but rather to place the decree of reversal which we shall render, upon the application to the facts of the well-settled doctrine on the subject of laches." 47 White thought the white Knights' failure to object to the black order's use of the name over many years, and the open and active existence of the black order in Georgia "leave no room for any other but the legal conclusion of laches." 48 Thus elementary principles of equity were violated by the injunction preventing the black Knights from using the name. ${ }^{40}$

Holmes, joined by Lurton, dissented in a particularly Delphic, almost impenetrable, paragraph. ${ }^{50}$ When a federal right was held by a state court to have been lost by subsequent conduct not in itself involving any federal question, such as laches, the Supreme Court had no jurisdiction to reverse unless the state court was in substance denying the right:

I do not see the distinction by which we can review the decision in the opposite case, where it is held that the right is not lost or that it cannot be interfered with because of laches on the other side. . . . I will content myself with saying that I do not see how the decision can be reversed on the ground of laches. ${ }^{51}$

(One can almost see Holmes bending over backward to affirm that he sits on a court of law and not on a court of justice.)

Holmes would probably be considered to have the better of the argument under modern theories of Supreme Court review, after Erie R.R. Co. $v$. Tompkins ${ }^{52}$ disavowed the notion of federal review of state court applications of general principles of the common law. After Erie, whether a state court should invoke laches to bar equitable relief would be considered a state law question, reviewable by the Supreme Court only if the doctrine were invoked in a manipulative way for the purpose of denying a federal right. Where a state court did not invoke the doctrine, and granted

47. Id. at 262 .

48. Id.

49. Although the laches issue was determinative, White could not quite resist pointing out that the Georgia courts had reached incompatible conclusions in finding that the black Knights had deceived the public and hurt the white order over many years, but that the white order had not known about the asserted injury until the black Knights sought state incorporation. Id. at 259, 262.

50. Id. at 263 (Holmes, J., dissenting).

51. Id.

52. 304 U.S. 64 (1937). 
equitable relief, the end result might as a matter of substance violate a federal right, but not because laches was not invoked, rather because as a matter of substance the state court's relief invaded a federal right. A plaintiff's federal right could be invaded by invocation of the doctrine of laches, but it is hard to see how a defendant's federal right could be invaded by noninvocation of laches against the plaintiff. Thus today, the Georgia courts' refusal to invoke laches in the Creswill situation would be considered a state law question beyond federal review. As Professor Alfred Hill has written: "It seems rather extraordinary that the Court should have deemed it proper in these circumstances to pass on the state ground." they had a federal right to use their name, not because the state court refused to honor their defense that the plaintiff had not made timely objection. In his Creswill dissent, Holmes revealed his positivist skepticism about the very idea of general principles of common law. Law was not a "brooding omnipresence," but rather the expression of sovereign power, and it followed for Holmes that unless a federal right was invaded, the state courts could make what they wanted of equity principles.

As matters stood in 1912, however, White and the majority were in keeping with accepted notions of federal review in taking on the whole case where a federal right was adjudicated under generally applicable common law principles. The opinion in Creswill is the work of an appellate judge bent on the correction of injustice, and White took pains to indicate that there were several possible grounds for reversing the Georgia courts before he fell back on the laches doctrine. Creswill thus reveals the majority's sense of justice. A summary affirmance could easily have rested on deference to the state court's findings, but the Supreme Court saw an injustice to the black Knights of Pythias and Edward Douglass White found a way to correct it. ${ }^{\text {.4 }}$

\section{Roads Not Taken}

Of the four main areas of law that cemented the wretched and deteriorating place of black people in American society during the Progressive era, the one most centrally involving courts of law was, oddly enough, the one the White Court let alone. Peonage, disfranchisement, and racial separation saw major decisions that began to uphold some of the promises of the Civil War Amendments. But the routine victimization of black people

53. Hill, supra note 44 , at 970 n.106.

54. For other decisions of the White Court extending protective federal jurisdiction to the Knights of Pythias based on its federal incorporation, but without racial implications, see Knights of Pythias v. Mims, 241 U.S. 574 (1916); Knights of Pythias v. Smyth, 245 U.S. 594 (1918); see also Ancient Egyptian Arabic Order of Nobles of the Mystic Shrine v. Michaux, 279 U.S. 737 (1929). 
in the administration of the criminal law was not touched by the White Court, partly because the evidence of discrimination, blatant as it seems in retrospect, lay beneath the face of statutes, and partly because notions of procedural justice were fixed on the rudimentary essentials of notice and a hearing, the minimal requisites of due process of law spelled out in Justice Moody's magisterial 1908 opinion in Twining $v$. New Jersey. ${ }^{\mathrm{bs}}$

Ironically, the most vigorous early statement of the anti-discrimination principle had come in a criminal procedure case. The state statute struck down in 1880 in Strauder $v$. West Virginia ${ }^{\text {s8 }}$ had excluded blacks from grand and petit juries. Between Strauder and the passing of Chief Justice White in 1921, all but one of the sixteen decisions handed down by the Supreme Court concerning racial discrimination in the criminal process involved the exclusion of blacks from juries. Pace v. Alabama ${ }^{57}$ in 1882 was the exception, an unsuccessful challenge to a statute that provided greater punishment for interracial adultery or fornication than it did for intraracial adultery or fornication.

Though peonage cases involved the criminal process and had important racial consequences, no explicit racial discrimination was at issue in them, and the Supreme Court downplayed the racial impact. None of the cases of the period dealt with the pervasive racial segregation in the courthouse, which extended from routine segregation of spectators on different sides of the courtroom to Jim Crow Bibles and witness stands, because this segregation rested on custom and official discretion rather than statutes. ${ }^{68}$ Nor did the Supreme Court deal with derogatory racial epithets and modes of address that were common in southern courtrooms around the turn of the century. ${ }^{68}$ Perhaps most warping to the possibility of equal justice, virtually every embodiment of the legal process in the South, from the police to the prosecutors to the courtroom functionaries up to the judges, was lilywhite. "No Negro holds a job in the courthouse higher than polishing

55. 211 U.S. 78 (1908).

56. 100 U.S. 303 (1880).

57. 106 U.S. 583 (1882).

58. See R. Baker, Following the Color Line 45, 96, 141 (1967).

59. In a major peonage prosecution that ended in acquittal in which the defendants were represented by the Attorney General-elect of Georgia, federal district judge Emory Speer made news when he admonished counsel:

[D]on't you think the future Attorney General of the state of Georgia can spare us this 'nigger, nigger, nigger'? It sounds so unworthy of a great court of justice, and so unworthy of your own position at the bar to be alluding to these poor unfortunate creatures constantly in the lowest terms of degradations.

A Recent Georgia Peonage Case: Throwing a Sidelight on Legal and Social Conditions in the South, 23 The Green Bag 525, 528 (1911). Neither the future Attorney General of Georgia nor most of the trial courts of the South shared Speer's punctilio. See, e.g., Franklin v. South Carolina, 218 U.S. 161,164 (1910) (repeated use of "nigger" to refer to defendant). 
spittoons," wrote William Archer in his 1910 Comparison of the Southern United States and South Africa. ${ }^{60}$

Juries, grand and petit, were the one agency of southern justice that blacks might realistically have had a chance to enter, and on which their presence might have ameliorated the harsh racial bias of law enforcement in the South. But after Strauder had invalidated a state law that in terms barred blacks from serving on juries, the focus of the jury discrimination cases shifted to laws and administration that still barred blacks from juries, but did so without saying that they did in so many words. ${ }^{61}$ Between 1880 and 1935, the Supreme Court utterly failed to come to grips with these new ways of rigidly, systematically excluding blacks from southern juries. I have written about this line of decisions and tried to analyze the complicated impotence of the federal courts in responding to jury discrimination claims, and I do not want to go over that ground again in these pages. ${ }^{62}$ What is most significant about the decisions in jury discrimination cases is what they did not do, but a few nonetheless call for mention as being of particular historical interest for other reasons.

One decision of this kind, touching on peonage as well as the question of the power to resist an unlawful arrest, was Franklin v. South Carolina ${ }^{\text {es }}$ decided in May 1910 in the last days of the Fuller Court. Franklin was the first case in which the fledgling NAACP launched a major intervention, and the case eventually came to touch such notables as President Taft, former Attorney General Charles J. Bonaparte, and Booker T. Washington, among others.

Pink Franklin, a black farmhand in South Carolina, had left the land and employ of a white planter in breach of contract and without repaying an advance. A sheriff and a deputy went to Franklin's home in the dead of night to arrest him for violating South Carolina's contract fraud law, a parallel provision to the Alabama peonage law struck down early in 1911 in Bailey $v$. Alabama. ${ }^{64}$ This law had already been declared invalid by

60. W. Archer, Through Afro-America, An English Reading of the Race Problem 89 (1910).

61. In Neal v. Delaware, 103 U.S. 370 (1881), one year after Strauder, the Supreme Court quashed the indictment of a black man who alleged that no blacks served on grand or petit juries. Delaware statutes did not sanction discrimination, but the state court conceded the exclusion of blacks in denying the defendant's notions: "that none but white men were selected is in nowise remarkable in view of the fact-too notorious to be ignored-that the great body of black men residing in this State are utterly unqualified by want of intelligence, experience, or moral integrity to sit on juries." Id. at 395. The Supreme Court, in reversing, called this "a violent presumption," and held that the uniform exclusion of blacks made out a prima facie case of the denial of equal protection of the laws. Id. at 397. See also Bush v. Kentucky, 107 U.S. 110 (1882) (setting aside murder indictment because Kentucky law excluded Blacks from grand jury).

62. Schmidt, supra note 19 , at $\mathbf{1 4 1 0 .}$

63. 218 U.S. 161 (1910).

64. 219 U.S. 219 (1911). 
both the federal district court in South Carolina and by the state supreme court, ${ }^{65}$ but this did not diminish the sheriff's zeal. A gunfight erupted under confused circumstances. Franklin, his wife, and his infant son were wounded, the sheriff was killed, and the deputy wounded. Franklin and his wife were arrested and very nearly lynched by a mob at the county jail. Franklin was eventually convicted of murder and sentenced to be hanged. As with most convictions of blacks that were reviewed in the Supreme Court in this period, a challenge to the make-up of the grand and petit juries, lily-white of course, was routinely made, but the jury question took a back seat to other claims thought to be weightier.

The issue that attracted most attention was whether a black sharecropper in the deep South sought to be arrested at gunpoint in dark of night under confused and threatening circumstances, under an invalid, and indeed invalidated, peonage statute, could resist with deadly force ${ }^{86}$ If Franklin's version of the arrest was to be believed, he was sleeping soundly when a stranger flung open his bedroom door, yelled "hands up" and then shot him without provocation, leading Franklin to scramble for his gun to defend himself. The state's evidence was that the sheriff had knocked on the door, called out to Franklin, and only entered after there was no response, whereupon Franklin shot him without warning. Whatever the facts, the plight of the black sharecropper awakened at gunpoint by an unknown man for violating an unconstitutional peonage law attracted national attention. In the Supreme Court, Charles J. Bonaparte, Attorney General in Theodore Roosevelt's second term, was retained by the Constitution League to submit a brief on Franklin's behalf. ${ }^{67}$

In a somewhat troubled opinion by Justice Day for a unanimous Court, all of Franklin's contentions were dismissed. The validity of drawing jurors from the lists of qualified voters was routinely affirmed in view of the absence of open discrimination on the face of South Carolina's suffrage statutes. Typical of many jury discrimination cases of this period, ${ }^{68}$ Day woodenly recited that it was essential for Franklin to show that the suffrage scheme actually operated to exclude blacks from juries, and he

65. Ex parte Drayton, 153 F. 986 (1907); Ex parte Hollman, 79 S.C. 9 (1907).

66. There were other issues: whether the state had unlawfully refused Franklin's evidence adduced at an inquest, whether the sheriff's dying declaration was admissible, and whether a continuance should have been granted.

67. The Constitution League was founded by a wealthy industrialist, John Milholland, to promote racial justice by court action, legislation, and publicity. A. MEIER, Negro ThOUght IN AMERICA: $1880-1915$, at 181 (1969).

Bonaparte submitted a brief, but was unable to persuade Franklin's black South Carolina lawyers, whose handling of the case in the state courts was patently inadequate, to let him become chief counsel in the Supreme Court. C. Kellogg, NAACP: A History of the National Association for the Advancement of Colored People 58 (1967); see also R. Kluger, Simple Justice 101 (1976).

68. See Schmidt, supra note 19 , at 1455-58. 
had failed to make this showing. It did not matter that jury commissioners operated under a vague mandate to select from the voter role "men of good moral character." ${ }^{\prime 8}$ Proof of actual exclusion was essential. ${ }^{70}$ Oddly, Day gave virtually no doctrinal consideration to the main issue pressed by Bonaparte-whether blacks could legally be "forbidden, on pain of death, to defend themselves against similar violent attempts to reduce them to virtual slavery"-although he referred to the grave questions raised by "eminent counsel" and he presented the contested claims about Franklin's arrest in evocative detail. However, despite the unanimity of the Court's rejection of Franklin's claims, the style of Day's opinion suggests that he, and perhaps others on the court, caught the odor of victimization that surrounded the case. It is a measure of the solid acquiescence of the Court in lily-white southern justice that a jury discrimination claim in such a case as Franklin did not stir any of the Justices to question the impotence of the Supreme Court's appellate process in placing on impecunious black defendants, usually "represented" by utterly passive white counsel, the burden of proving racial exclusion across a whole hidden and discretionary system of jury selection.

The great historical importance of the Franklin case did not rest on the Supreme Court's handling of it. After Franklin's appeal failed, the case became the first one taken up by the then new NAACP, although only in pardon proceedings. The NAACP made a major, and eventually successful, effort to have the Governor of South Carolina commute Franklin's death sentence to life imprisonment, enlisting in the effort, among others, President Taft and Booker T. Washington. The NAACP did not stop there. Nine years later, after extensive NAACP efforts, Franklin was finally set free. ${ }^{71}$

During the time that White was Chief Justice, the Supreme Court declined at least two other chances to deal with the problem of jury discrimination, in both cases on justifiable but not quite compelling grounds of avoidance. Kitchens v. Hamilton ${ }^{72}$ was, like the Franklin case, the judicial residue of a violent interaction between black and white that conveyed an aura of lawlessness and victimization.

Robert Kitchens, his brother, and his cousin, were charged by an allwhite Georgia grand jury with murdering one Henry Brantley, a white man, immediately after Brantley had allegedly beaten and sexually molested Kitchens' 12-year-old sister. Three other family members were indicted as accessories. An all-white petit jury convicted Kitchens and he

69. Franklin, 218 U.S. at 168.

70. Id.

71. See C. Kellogg, supra note 67 , at 59.

72. 239 U.S. 637 (1916). 
was sentenced to be hanged. Kitchens did not raise the jury discrimination issue at trial, and the Georgia courts therefore refused to consider the claim, despite Kitchens' contention that it was fear of mob violence at the trial that had prevented his white lawyer from raising the jury exclusion claim. Kitchens sought habeas in the Georgia federal district court before Judge Emory Speer, but was denied relief, without hearing or opinion. In the Supreme Court, Kitchens bolstered this discrimination claim with the argument that the Georgia law pertaining to jury selection was so vague as to invite the exclusion of blacks. Under the Georgia Constitution, jurors were to be limited to "the most experienced, intelligent and upright men."73 On January 17, 1916, the Court affirmed without opinion on the authority of Andrews $v$. Swartz ${ }^{\mathbf{7 4}}$ and Frank $v$. Mangum. ${ }^{\mathbf{7 5}}$

The other case disposed of without opinion that might have tested the legality of jury discrimination was Moore $v$. Arkansas, ${ }^{78}$ handed down in 1920, the initial appeal of the celebrated case that led three years later to the landmark habeas decision, Moore $v$. Dempsey. ${ }^{77}$ The case grew out of the bloody race riot in eastern Arkansas in September 1919, one of the pattern of race riots that rocked the United States in the bloody summer of $1919 .{ }^{78}$ A group of black tenant farmers that had organized a union to deal with their grievances against the white landowners were meeting in a church in Hoop Spur in Phillips County, and, depending on whose version of the events is believed, were either fired upon by two white deputies or attacked the deputies without provocation. One deputy was killed, the other wounded. As rumors swept the county that blacks had organized to massacre whites, the sheriff swore in 300 deputies and the governor called in 500 soldiers from the U.S. Army. Armed white bands went on a murderous rampage. A handful of whites and somewhere between 25 and 200 blacks were killed in the resulting violence. ${ }^{79}$ Several hundred blacks were taken into custody and there is much evidence of widespread torture in the interrogations and confinements that followed. ${ }^{80}$ Federal and state authorities treated the events as virtually a full-scale black insurrection.

Moore was among the first group tried of the more than one hundred blacks indicted for various offenses. As armed mobs surrounded the courthouse in Elaine, Arkansas, a travesty of justice produced death sentences

\footnotetext{
73. GA. Const. art. iv, $\S 16$.

74. 156 U.S. 272 (1895).

75. 237 U.S. 309 (1915).

76. 254 U.S. $630(1920)$.

77. 261 U.S. 86 (1923).

78. See A. Waskow, From Race Riot to Sit-In, 1919 and the 1960's 121 (1966).

79. R. KLUGER, supra note 67, at 112-115.

80. The only white arrested was a lawyer who had agreed to help the black sharecroppers' association press their claims. Id.
} 
in less than an hour as Moore and five others were sentenced to die for murdering the deputy who had been shot at Hoop Spur. Among Moore's many points on appeal were that blacks had been excluded from the grand and petit juries that indicted and convicted him, that counsel appointed to represent him had been ineffective, that a mob had dominated his trial and intimidated all the participants, and that the state's witnesses had been tortured into giving their incriminating testimony. The white lawyer assigned to represent Moore and the others had no access to the black defendants before the trial and put on no witnesses in their behalf. Moreover, Moore's counsel did not raise the jury discrimination claim at trial, because he was, succeeding counsel claimed, intimidated and incompetent.

The Arkansas Supreme Court refused to consider Moore's jury discrimination complaint, since it had not been raised at the trial. ${ }^{\mathbf{8 1}} \mathrm{A}$ writ of certiorari was sought in the Supreme Court in October 1920, but was denied. The inflamed injustice of the criminal process in Phillips County, Arkansas, would not be noticed in the Supreme Court until Moore v. Dempsey was decided in 1923.

\section{ConCLusion}

The cases discussed so far in this postscript all arose in the South. I conclude with mention of a case that shows both the painful and absurd lengths to which the drive for racial separation was pressed, and that the North was prone to the pressure of Jim Crow, as well. For me, it is the most poignant of the race cases of this period, although as with others discussed it was hardly touched by the Supreme Court.

On March 8, 1915, the Supreme Court dismissed for want of jurisdiction Gaskill v. Forest Home Cemetery, ${ }^{\mathbf{8 2}}$ a case that foreshadowed a problem that would split the Supreme Court forty years later in Rice $v$. Sioux City Memorial Park Cemetery. ${ }^{83}$ Gaskill challenged an exclusion on account of race of a body from a cemetery just outside of Chicago, Illinois. Mr. and Mrs. John B. Gaskill had buried four of their children in the Forest Home Cemetery between 1890 and 1906, but by the time Mrs. Gaskill died in 1912, the cemetery had adopted a policy of interring white people only because, "Many of our patrons of the white race object to the burial of the remains of the colored race in their proximity." The management sent regrets that the mother would not be permitted to lie in repose with her children: "We have no personal prejudice or ill feeling

81. Hicks v. State, 143 Ark. 158, 220 S.W. 308 (1920).

82. 238 U.S. 606 (1915).

83. 348 U.S. 880 (1954); cert. dismissed as improvidently granted, 349 U.S. 70 (1955) 
toward the colored people . . . but we must do what is best for our business regardless of personal feeling." ${ }^{84}$ Gaskill sued in the Illinois courts, asserting that the exclusion violated the Fourteenth Amendment. He did not clear the state action hurdle. The cemetery was not required by its corporate charter to serve all customers, it did not have the power of eminent domain, it was not a monopoly, and therefore it was not impressed with constitutional obligations applicable to the state, reasoned the Supreme Court of Illinois. ${ }^{85}$ The United States Supreme Court heard argument in the case but saw no need for an opinion. Its summary disposition cited six cases in support of its dismissal, none of which involved racial discrimination and all of which were cases in which state law was held to govern the outcome of various commercial transactions. The Court's dismissal provoked no notice in either the daily press in Chicago or Washington, or in legal periodicals. But perhaps it is not too late in an issue honoring the work of Charles Black to remember Mrs. Gaskill and her separation after life from her children.

84. These statements were included in Gaskill's petition to the Illinois Courts and were part of the record before the Supreme Court.

85. Gaskill v. Forest Home Cemetery Co., 258 Ill. 36, 101 N.E. 219 (1913). 